Ann. Biol. anim. Bioch. Biophys., I975, 15 (2), 365-367.

\title{
INTENSIVE LAMB PRODUCTION
}

\author{
J. THIMONIER, Y. COGNIE, C. CORNU, J. SCHNEBERGER \\ and G. VERNUSSE
}

Station de Physiologie de la Reproduction, Centre de Recherches de Tours, I. N.R. A., 37380 Nouzilly (France)

The method of management of the sheep flock at the Station de Physiologie de la Reproduction, I. N. R. A., Nouzilly, near Tours, is based on a combination of techniques :

I. Symchronization and/or induction oestrus : the most widely used method is that of vaginal sponges (RoBINSON, 1965) impregnated with fluorogestone acetate. The action of the progestagen is completed by that of PMSG. The duration of treatment, the quantity of progestagen and of PMSG depend on the breed, season and physiological state of the females.

It is possible to synchronize and/or to induce oestrus and ovulation, and to obtain high fertility after insemination, regardless of the season :

- in ewes, more than 3 months after parturition (dry ewes),

- in lambs, on condition however, that they are at least 6 to 7 months of age, and have a weight greater than $60 \mathrm{p}$. Ioo of that of adult females of the same breed,

- in ewes, 40-50 days after parturition, wether they are dried or lactating.

2. Artificial insemination without prior detection of oestrus, either with fresh diluted sperm, or with frozen and conserved sperm. The number of inseminations ( $\mathrm{x}$ or 2 ) and the number of sperm depend on the physiological state of the females-dry ewes, lambs, lactating or dried ewes (CoLAs, I975).

3. Early diagnosis of pregnancy by estimation of the level of peripheral plasma progesterone. A blood sample is taken from all females $\mathbf{I} 8$ days after insemination. All females diagnosed as not pregnant do not give birth. Only $80-90$ p. Ioo of females presumed pregnant, ultimately give birth. The variability of the oestrous cycle length, and precocious embryonic mortality account for the difference between the number of females presumed pregnant and those which give birth (THIMONIER, I973).

4. Induction of parturition by administration of dexamethasone (Bosc, I970) or oestradiol benzoate (TERQUr et al., I975) results in 90-95 p. Ioo of treated females lambing over a 48 hour period. In addition, when dexamethasone is administered in the evening, $70 \mathrm{p}$. Ioo of females lamb between 6-I 8 hrs. By reducing the lambing 
period, the induction of parturition facilitates supervision and allows a diminution in perinatal mortality (Bosc, I973).

5. Precocious weaning and artificial lactation. At 52 days after parturition, the fertility of ewes dried 2 days after lambing, is higher than that of lactating females, especially during the anoestrous period (CoGNIE et al., I974). Early weaning of ewes is thus used when lambing occurs between January and June. The lambs are then artificially fed with warm reconstituted milk distributed by an automatic machine (200 g of milk powder containing $24 \mathrm{p}$. roo fat for I liter of water).

\section{Flock management}

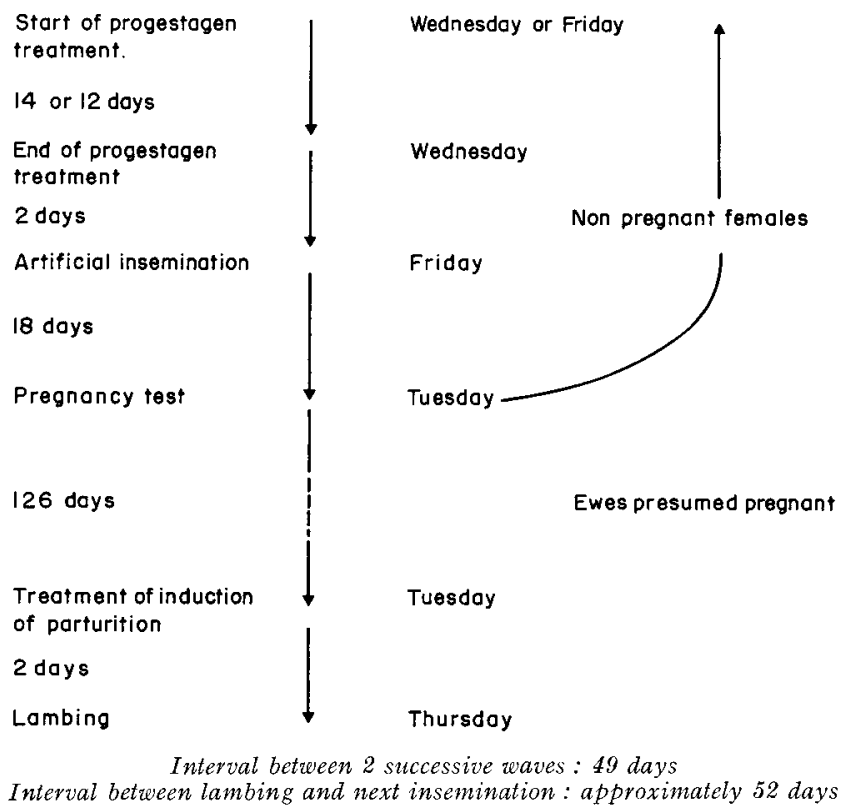

The duration of artificial feeding is 45 days (including weaning). The lambs are then fed with dehydrated lucerne and cereals. They are sold when they have reached a weight of between 30 and $35 \mathrm{~kg}$ at an age around I IO days (THERIEZ, I975).

The association of these techniques has been integrated in a scheme of flock management which allows the reduction of a large amount of work (treatment, inseminations, lambing) during the weekends.

This scheme is not the most intensive that could be conceived. It does not, in fact, take into account the existence of returns to oestrus of non-pregnant females at certain times of the year.

Nevertheless, with Romanov and Prealpes crossbred females, it has been possible to obtain 3 lambs per female per year. 


\section{RÉSUMÉ,}

\section{PRODUCTION INTENSIVE D'AGNEAUX}

En combinant les techniques de synchronisation de l'estrus, d'insémination artificielle, de détection précoce de la gestation et d'induction de la parturition, on peut conduire un troupeau de Brebis en respectant une semaine de travail de cinq jour's et obtenir jusqu'à trois agneaux par femelle et par an.

\section{RÉFÉRENCES BIBLIOGRAPHIQUES}

Bosc M. J., I97o. Étude de l'induction de la parturition chez les Brebis par un corticostéroïde de synthèse, le fluoro-méthyl prednisolone. C. R. Acad. Sc., Paris, Sér D, 270, 3127-3130.

Bosc M. J., I973. Données actuelles sur le contrôle de la parturition chez la Brebis et la Vache. Rec. Méd. Vét., 149, I463-I480.

Cognie Y., Cornu C., Mauleon P., i974. The influence of lactation on fertility of ewes treated during post partum anoestrus with vaginal sponges impregnated with fluorogestone acetate (chronogest). Intern. Symp. ou physio-pathology of reproduction and artificial insemination in small Ruminants. Proceedings, Thessaloniki, 33-36.

Colas G., r975. The use of progestogen SC 9880 as an aid for artificial insemination in ewes. Ann. Biol. anim. Bioch. Biophys, 15, 31.7-327.

Robinson T. J., I965. Use of progestagen impregnated sponges inserted intravaginally or subcutaneously for the control of oestrus cycle in the sheep. Nature, 206, 39-4I.

Tergur M., Delouis C., KANN G., r975. Levels and effects of oestrogens during pregnancy and parturition in the ewe (in préparation).

Theriez M., 1975. L'allaitement artificiel des agneaux dans les troupeaux de l'I. N. R. A. In L'allaitement artificiel des agneaux et des chevreaux. I. N. R. A.-S. E. I., 69-8I.

Thimonier J., 1973. Diagnostic précoce de gestation par l'estimation du taux de progestérone plasmatique chez la Brebis, la Vache et la Jument. Rec. Méd. Vét., 149, 1303-1318. 